\title{
The effect of marine oil-derived $n-3$ fatty acids on transepithelial calcium transport in Caco-2 cell models of healthy and inflamed intestines
}

\author{
Jennifer Gilman ${ }^{1}$ and Kevin D. Cashman ${ }^{1,2 *}$ \\ ${ }^{1}$ Department of Food and Nutritional Sciences and \\ ${ }^{2}$ Department of Medicine, University College, Cork, Republic of Ireland
}

(Received 9 February 2006 - Revised 6 July 2006 - Accepted 6 July 2006)

\begin{abstract}
Marine oil-derived $n-3$ fatty acids have been shown to stimulate intestinal Ca absorption in animal studies, but the effects of such fatty acids on Ca absorption in human subjects are relatively unknown. In particular, $n-3$ fatty acids may be of therapeutic value for some Crohn's disease patients who experience Ca malabsorption. Therefore, the aim of the present study was to investigate the effect of $20: 5 n-3$ and $22: 6 n-3$ on transepithelial $\mathrm{Ca}$ transport across monolayers of healthy Caco- 2 cells as well as of TNF- $\alpha$-treated Caco- 2 cells (an in vitro model of Crohn's disease). Caco- 2 cells were seeded onto permeable filter supports and allowed to differentiate into monolayers, which were treated with $80 \mu \mathrm{M}-20: 5 n$ - $3,80 \mu \mathrm{M}$ $22: 6 n-3$, or $40 \mu \mathrm{M}-20: 5 n-3+40 \mu \mathrm{M}-22: 6 n-3$ for 6 or $8 \mathrm{~d}$, with or without co-treatment with TNF- $\alpha(10 \mathrm{ng} / \mathrm{ml})(n 11-15$ monolayers per treatment). On day 16, transepithelial and transcellular transport of ${ }^{45} \mathrm{Ca}$ and fluorescein transport (a marker of paracellular diffusion) were measured. Treatment of healthy and inflamed Caco-2 cells with $20: 5 n-3,22: 6 n-3$ and both fatty acids combined for $8 \mathrm{~d}$ significantly $(P<0 \cdot 005-0 \cdot 01)$ increased total transepithelial Ca transport compared with that in control, effects which were mediated by an enhanced rate of transcellular Ca transport. The effects of $n-3$ fatty acids on Ca absorption after $6 \mathrm{~d}$ were less clear-cut. In conclusion, the present in vitro findings highlight the need to investigate the effect of marine oil-based $n-3$ fatty acids on Ca absorption in vivo in studies of healthy human subjects as well as of Crohn's disease patients.
\end{abstract}

n-3 Fatty acids: Calcium absorption: Caco-2 cells: Tumour necrosis factor- $\alpha$

The effect of dietary factors on $\mathrm{Ca}$ absorption is poorly understood and there is a need for detailed studies to define the ways in which food components and functional food ingredients influence $\mathrm{Ca}$ absorption in order to determine how $\mathrm{Ca}$ bioavailability from foods can be optimised (Kennefick \& Cashman, 2000). Evidence principally from animal studies suggests that $n-3$ fatty acids, especially those from marine oils, could stimulate intestinal $\mathrm{Ca}$ absorption and promote bone health (for reviews, see Kruger \& Horrobin, 1997; Watkins et al. 2001), and thus may be potential functional food ingredients. However, there have been no studies in human subjects of the effect of marine oil-based $n-3$ fatty acids on $\mathrm{Ca}$ absorption. Such fatty acids may also be of potential use for promoting $\mathrm{Ca}$ absorption in 'at-risk' individuals.

Osteopenia and osteoporosis are common conditions among patients with Crohn's disease. Osteopenia is seen in about $30 \%$ of Crohn's disease patients, while $10-12 \%$ of patients have osteoporosis (Bjarnason et al. 1997; Szulc \& Meunier, 2001). The pathogenesis of osteopenia and osteoporosis in Crohn's disease is likely to be multifactorial, and has been attributed to an adverse effect of sex hormone deficiency, reduced physical activity, prolonged corticosteroid therapy, bowel surgery, smoking, and the potential deleterious effects of circulating cytokines and other mediators (for example, IL- 1 and IL- 6 and TNF- $\alpha$ ) released by the inflamed intestines on bone metabolism (Pollak et al. 1998). Another pathogenic mechanism which has been implicated in the low bone mineral density in Crohn's disease is the existence of one or more nutritional inadequacies in these patients. For example, several studies have reported an association between low bone mineral density and a reduced intake or malabsorption of Ca (Bernstein et al. 1996; Silvennoinen et al. 1996; Scott et al. 2000), as well as a deficiency of vitamins D and/or K (Arnaud et al. 1975; Compston \& Creamer, 1977; Schoon et al. 2001; Haderslev et al. 2003; Duggan et al. 2004). Therefore, improvement of nutritional status must form part of the overall strategy for prevention of osteoporosis in Crohn's disease patients.

In addition to possible beneficial effects on intestinal $\mathrm{Ca}$ absorption in Crohn's disease patients, $n-3$ fatty acids have also been shown to alleviate intestinal inflammation in Crohn's disease patients, and thus are considered possible preventative and/or therapeutic agents for the disease itself (Endres et al. 1999; Belluzzi, 2002; Cashman \& Shanahan, 2003). In this way, $n-3$ fatty acids may indirectly benefit bone, by lessening the deleterious effects of circulating cytokines and other mediators (for example, IL-1, IL-6 and TNF- $\alpha$ ) released by the inflamed intestines, on bone. Thus, the use of $n-3$ fatty acids could benefit intestinal $\mathrm{Ca}$ absorption, while calming intestinal inflammation in Crohn's 
disease patients, both of which may help reduce the risk of osteoporosis and osteopenia in these patients. However, this has not been investigated.

Therefore, the objective of the present study was to investigate the effect of two $n-3$ fatty acids, namely $20: 5 n-3$ and $22: 6 n-3$, on $\mathrm{Ca}$ transport across normal and inflamed polarised human intestinal epithelial (Caco-2) cell monolayers. Caco-2 cells have been suggested to be a suitable model for predicting $\mathrm{Ca}$ absorption in man (Giuliano \& Wood, 1991; Fleet \& Wood, 1999). Recent work has shown that these cells respond, in terms of $\mathrm{Ca}$ absorption, to fatty acid intervention (Jewell \& Cashman, 2003; Jewell et al. 2005). In addition, Caco- 2 cells secrete inflammatory cytokines when treated with TNF- $\alpha$ (Lang et al. 2004). Therefore, this relatively simple in vitro method appears to be a good model for predicting the effect of $n-3$ fatty acids on Ca absorption in healthy human subjects as well as in Crohn's disease patients.

\section{Materials and methods}

\section{Materials}

Tissue culture materials, including Dulbecco's modified Eagle's medium with L-glutamine and sodium bicarbonate, fetal bovine serum, minimum essential medium, non-essential amino acids and PBS were purchased from Sigma-Aldrich Ireland Ltd (Dublin, Republic of Ireland). ${ }^{45} \mathrm{Ca}$ (as ${ }^{45} \mathrm{Ca}$ in an aqueous solution of $\mathrm{CaCl}_{2}$, with a specific activity of $1.85 \mathrm{MBq} / \mathrm{mg} \mathrm{Ca}$ ) was purchased from Nensure ${ }^{\mathrm{TM}}$ (Boston, MA, USA). Fluorescein Na salt, 3-(4,5-dimethylthiazol-2yl)-2,5-diphenyltetrazolium bromide (MTT), 20:5n-3, $22: 6 n-3$ and TNF- $\alpha$ were purchased from Sigma-Aldrich Ireland Ltd.

\section{Conditions of cell culture}

The human colon adenocarcinoma cell line, Caco-2, was purchased from the European Collection of Animal Cell Cultures (Salisbury, Wiltshire, UK). Cells were routinely grown in $75 \mathrm{~cm}^{2}$ plastic culture flasks (Costar, Cambridge, MA, USA) in Dulbecco's modified Eagle's medium supplemented with non-essential amino acids $(10 \mathrm{ml} / \mathrm{l})$ and fetal bovine serum $(100 \mathrm{ml} / \mathrm{l})$. Caco-2 cells were maintained at $37^{\circ} \mathrm{C}$ in a $\mathrm{CO}_{2}$-air $(5: 95, \mathrm{v} / \mathrm{v})$ atmosphere. Cells were seeded at $3 \times 10^{4} / \mathrm{cm}^{2}$ and passaged when reaching $90 \%$ confluency. Cells used in transepithelial $\mathrm{Ca}$ transport experiments were seeded at a density of $3 \times 10^{4} / \mathrm{cm}^{2}$ onto permeable Transwell $^{\circledR}$ filter inserts $(24 \mathrm{~mm}$ diameter, $0.4 \mu \mathrm{m}$ pore size; Costar). Cell culture media was changed on alternate days for $15 \mathrm{~d}$. For IL-8 studies, cells $\left(3 \times 10^{4} / \mathrm{cm}^{2}\right)$ were seeded onto Transwell ${ }^{\circledR}$ filter inserts (Costar). For viability studies, cells $\left(3 \times 10^{4} / \mathrm{cm}^{2}\right)$ were seeded into forty-eight-well culture plates (Costar).

\section{Cell viability assays}

The effect of TNF- $\alpha, 20: 5 n-3,22: 6 n-3$ and $20: 5 n-3+22: 6 n-3$ on Caco- 2 cell viability was investigated using the MTT assay in forty-eight-well culture plates (Costar), as described by Mossman (1983) and Edmonson et al. (1988). Results were expressed as a percentage of the control value, representing the surviving fraction relative to control samples. A value $<85 \%$ of the control value was taken as a benchmark for toxicity.

\section{Transepithelial electrical resistance}

For all transport experiments, the transepithelial electrical resistance (TEER; a measure of the integrity of polarised epithelial cell monolayers) was checked before the experiment by a Millicell ${ }^{\circledR}$ ERS meter (Millipore Corporation, Bedford, MA, USA) connected to a pair of thin side-by-side electrodes as described by Tanaka et al. (1995). TEER readings were taken at $37^{\circ} \mathrm{C}$. A TEER value $\geq 1500 \Omega \times \mathrm{cm}^{2}$ was used as an indicator that the epithelial layer was intact and ready to use for $\mathrm{Ca}$ transport studies.

\section{Cell treatments}

Two different approaches were used in the present study: (1) pre-treatment of Caco- 2 cells with $n$-3 fatty acids before co-treatment with pro-inflammatory $\mathrm{TNF}-\alpha$ (nominally referred to as preventative studies); (2) treatment of Caco-2 cells with TNF- $\alpha$ followed by co-treatment of Caco- 2 cells with $n-3$ fatty acids (nominally referred to as therapeutic studies).

Preventative studies. For Ca transport experiments, cells grown in the Transwell ${ }^{\circledR}$ inserts were treated with vehicle only (for control), $80 \mu \mathrm{M}-20: 5 n-3,80 \mu \mathrm{M}-22: 6 n-3$, or $40 \mu \mathrm{M}-$ $20: 5 n-3+40 \mu \mathrm{M}-22: 6 n-3$ for $6 \mathrm{~d}$ followed by co-treatment with TNF- $\alpha(10 \mathrm{ng} / \mathrm{ml})$ or vehicle for a further $48 \mathrm{~h}$ (which was shown in a pilot study to be sufficient to induce biomarkers of inflammation in Caco-2 cells, including IL-8). We have previously found that $6 \mathrm{~d}$ is sufficient to allow fatty acid uptake into Caco-2 cells (Ryan, 2004). All compounds were added to complete culture medium before their addition to the cells. The vehicle never exceeded $1 \mathrm{ml} / \mathrm{l}$. TEER measurements were taken immediately before treatment with test compounds and after treatment.

Therapeutic studies. For Ca transport experiments, cells grown in the Transwell ${ }^{\circledR}$ inserts were treated with TNF- $\alpha$ $(10 \mathrm{ng} / \mathrm{ml})$ or vehicle only (for control) for $48 \mathrm{~h}$ followed by co-treatment with vehicle only, $80 \mu \mathrm{M}-20: 5 n-3,80 \mu \mathrm{M}-$ $22: 6 n-3$, or $40 \mu \mathrm{M}-20: 5 n-3+40 \mu \mathrm{M}-22: 6 n-3$ for a further 6 d. All compounds were added to complete culture medium before their addition to the cells. The vehicle never exceeded $1 \mathrm{ml} / \mathrm{l}$. TEER measurements were taken immediately before treatment with test compounds and after treatment.

\section{Transepithelial calcium transport studies}

The method used for determining Ca transport across the Caco-2 membrane in the present study is a modification of the methods of Giuliano \& Wood (1991) and Fleet \& Wood (1994). Transepithelial transport of Ca was studied with Caco-2 cells grown on permeable membrane supports for $15 \mathrm{~d}$, by which time the cells are fully differentiated. On the day of an experiment, the medium containing test compounds was removed and the inserts rinsed with buffer. The buffer was prepared fresh before use and consisted of $140 \mathrm{mM}-\mathrm{NaCl}, 5.8 \mathrm{mM}-\mathrm{KCl}$, $1.2 \mathrm{mM}^{-\mathrm{CaCl}_{2}}, 0.8 \mathrm{~mm}-\mathrm{MgSO}_{4}, 0.44 \mathrm{~mm}-\mathrm{KH}_{2} \mathrm{PO}_{4}, 0.34 \mathrm{~mm}-$ $\mathrm{Na}_{2} \mathrm{HPO}_{4}, 4 \mathrm{~mm}$-glutamine, $25 \mathrm{~mm}$-glucose and $20 \mathrm{~mm}$-HEPES 
(pH 7.4). After rinsing, $2.6 \mathrm{ml}$ of this buffer was added to the lower chamber of the Transwell ${ }^{\circledR}$ (Costar, Cambridge, MA, USA) inserts. At time zero, $1.5 \mathrm{ml}$ of transport buffer was added to the upper chamber of the Transwell ${ }^{\circledR}$ (Costar) inserts. This consisted of the same buffer as the lower chamber (see composition of buffer earlier) except it also contained ${ }^{45} \mathrm{Ca}$ (with an activity of $148 \mathrm{kBq} / \mathrm{ml}$ ) and $5.3 \mathrm{~mm}$-fluorescein (as the $\mathrm{Na}$ salt). Fluorescein was included in the transport buffer, in place of phenol red, as used by Fleet \& Wood (1994), as a means of measuring paracellular (diffusional) transport across the Caco-2 monolayer (Lindmark et al. 1998). Following the addition of the transport buffer to the Transwell ${ }^{\circledR}$ (Costar) inserts, the plates were covered and incubated at $37^{\circ} \mathrm{C}$ in a shaking water-bath (set to 48 oscillations per min) for $60 \mathrm{~min}$. At 30 and $60 \mathrm{~min}$ after addition of ${ }^{45}$ Ca-labelled transport buffer, duplicate samples $(10 \mu \mathrm{l})$ of the buffer from the lower chamber (basolateral buffer) were taken from each well and placed in wells of a blackened ninety-six-well plate (Costar). When samples had been taken at both time points, $200 \mu \mathrm{l} 50 \mathrm{~mm}-n$-ethylmorpholine buffer ( $\mathrm{pH} 8.0)$ was added to each of the ninety-six wells and fluorescence (excitation, $485 \mathrm{~nm}$; emission, $535 \mathrm{~nm}$ ) was measured in a Spectrafluor + Tecan fluorescence plate reader (Tecan AG, Hombrechtikon, Switzerland). In addition, at the same time points duplicate samples $(50 \mu \mathrm{l})$ of the basolateral buffer were taken for determination of ${ }^{45} \mathrm{Ca}$ content. Samples of the basolateral buffer were placed in scintillation vials and $5 \mathrm{ml}$ of liquid scintillation cocktail (biodegradable counting scintillant; Amersham International plc, Little Chalfont, Bucks, UK) was added to each vial. Counts were measured on a Beckman LS 6500 multipurpose liquid scintillation counter (Beckman Instruments, Inc., Fullerton, CA, USA). An equal volume of fresh basolateral buffer was added back to the lower chamber following each sampling point. The concentration of fluorescein appearing in the lower buffer after 60 min was determined using a standard curve of fluorescein and this value was expressed as a percentage of the total fluorescein added to the upper chamber of the Transwell ${ }^{\circledR}$ inserts (Costar). This represented the paracellular route of $\mathrm{Ca}$ transport. The amount of ${ }^{45} \mathrm{Ca}$ appearing in the basolateral buffer was expressed as a percentage of the total ${ }^{45} \mathrm{Ca}$ applied to the upper chamber. This represented total transepithelial ${ }^{45} \mathrm{Ca}$ transport (i.e. by both the paracellular and transcellular transport routes) and was expressed as nmol transported/min per well during the 30-60 min time interval. The amount of ${ }^{45} \mathrm{Ca}$ crossing the Caco- 2 cell monolayer by the transcellular (active) route was calculated by subtracting the paracellular contribution from total transepithelial $\mathrm{Ca}$ transport, and both paracellular and transcellular Ca transport were expressed as nmol/well per min. In all studies, at least three wells were examined per treatment. Experiments were repeated at least three times.

\section{Secretion of interleukin-8 by Caco-2 monolayers}

The concentration of IL- 8 secreted from Caco- 2 monolayers (as a biomarker of intestinal cell inflammation) was determined using a recently developed ELISA (Human IL-8 DuoSet ELISA Development System; R\&D Systems Europe Ltd, Abingdon, Oxon, UK), as described elsewhere (O'Hara et al. 2006).

\section{Statistical methods}

The Ca transport (total and paracellular) data from preventative studies, paracellular $\mathrm{Ca}$ transport data from therapeutic studies, and IL-8 data from both sets of studies were not normally distributed and, therefore, values were logarithmically (natural $\log$; Ln) transformed before statistical analysis, to achieve near-normal distributions. Transcellular $\mathrm{Ca}$ transport data, and total and transcellular $\mathrm{Ca}$ transport data, from the preventative and therapeutic studies, respectively, and TEER data from both sets of studies were normally distributed. All data were subjected to two-way ANOVA, with variation attributed to fish oil treatment and TNF- $\alpha$ treatment (Snedecor \& Cochran, 1967). In some cases, where applicable, data were subjected to one-way ANOVA, with variation attributed to fish oil treatment (Snedecor \& Cochran, 1967). Results are presented as mean values with their pooled standard errors. Where applicable, when data were Ln-transformed, for ease of interpretation, the data were back-transformed to geometric means. To follow up the ANOVA, all pairs of means were compared by the method of least significant difference (Snedecor \& Cochran, 1967).

\section{Results}

There was no effect of $80 \mu \mathrm{M}-20: 5 n-3,80 \mu \mathrm{M}-22: 6 n-3$ or $40 \mu \mathrm{M}-20: 5 n-3+40 \mu \mathrm{M}-22: 6 n-3$ on Caco- 2 cell survival and viability as determined using the MTT assay, which is based on mitochondrial dehydrogenase activity (data not shown). Higher concentrations of $20: 5 n-3$ and $22: 6 n-3$ produced some evidence of reduced cell viability, as did the combination of $80 \mu \mathrm{M}-20: 5 n-3+80 \mu \mathrm{M}-22: 6 n-3$ (data not shown). In addition, exposure of Caco- 2 cells to TNF- $\alpha$ $(10 \mathrm{ng} / \mathrm{ml})$ for $8 \mathrm{~d}$ had no effect on cell viability (data not shown).

\section{Preventative studies}

Total transepithelial Ca transport across fully differentiated Caco-2 cell monolayers was significantly increased by lipid treatment $(P<0.0001)$ and $\mathrm{TNF}-\alpha$ treatment $(P=0.0003)$, with a significant $(P<0.05)$ interaction between the two factors (Table 1). Treatment of Caco-2 cell monolayers with $80 \mu \mathrm{M}-20: 5 n-3$ and $80 \mu \mathrm{M}-22: 6 n-3$ significantly $(P<0 \cdot 005)$ increased total transepithelial Ca transport compared with control, irrespective of whether the cells were untreated or treated with TNF- $\alpha$ (Table 1). Treatment of Caco-2 cell monolayers with $40 \mu \mathrm{M}-20: 5 n-3+40 \mu \mathrm{M}-22: 6 n-3$ also significantly $(P<0 \cdot 01)$ increased total transepithelial $\mathrm{Ca}$ transport compared with control, with no significant differences between $20: 5 n-3+22: 6 n-3$ and either $20: 5 n-3$ or $22: 6 n-3$ alone, irrespective of whether the cells were untreated or treated with TNF- $\alpha$ (Table 1). Total transepithelial Ca transport across TNF- $\alpha$-treated Caco- 2 cells was significantly higher in control (non-lipid-treated) cells and those treated with $22: 6 n-3$, but not in cells treated with $20: 5 n-3$ or $20: 5 n-3+22: 6 n-3$, compared with the equivalent groups not treated with TNF- $\alpha$ (Table 1).

Transcellular Ca transport across fully differentiated Caco-2 cell monolayers was significantly increased by lipid treatment $(P<0.0001)$ and TNF- $\alpha$ treatment $(P=0.001)$, but there was 
no significant $(P>0 \cdot 1)$ interaction between the two factors (Table 1). Treatment of Caco-2 cell monolayers with $80 \mu \mathrm{M}-$ $20: 5 n-3, \quad 80 \mu \mathrm{M}-22: 6 n-3$ and $40 \mu \mathrm{M}-20: 5 n-3+40 \mu \mathrm{M}-$ $22: 6 n-3$ significantly $(P<0.001)$ increased transcellular $\mathrm{Ca}$ transport compared with control, irrespective of whether the cells were untreated or treated with TNF- $\alpha$ (Table 1).

Paracellular Ca transport across fully differentiated Caco-2 cell monolayers (representing only 4-6\% of total transepithelial $\mathrm{Ca}$ transport) was significantly influenced by lipid treatment $(P \leq 0.004)$, but was unaffected by TNF- $\alpha$ treatment and there was no significant $(P>0 \cdot 1)$ interaction between the treatments (Table 1).

TEER across fully differentiated Caco- 2 cell monolayers was significantly $(P=0.002)$ increased by lipid treatment and significantly $(P=0.002)$ decreased by TNF- $\alpha$ treatment, but there was no significant $(P>0.05)$ interaction between the two factors. Treatment of Caco-2 cell monolayers with $80 \mu \mathrm{M}-20: 5 n-3$, $80 \mu \mathrm{M}-22: 6 n-3$ and $40 \mu \mathrm{M}-20: 5 n-3+40 \mu \mathrm{M}-22: 6 n-3$ significantly $(P<0.001)$ increased TEER compared with control, irrespective of whether the cells were untreated or treated with TNF- $\alpha$ (Table 1).

IL-8 secretion from fully differentiated Caco-2 cell monolayers was significantly increased by TNF- $\alpha$ treatment $(P \leq 0.0001)$, but was unaffected by lipid treatment $(P>0.05)$ and there was no significant $(P>0.05)$ interaction between the treatments (Fig. 1(A)).

\section{Therapeutic studies}

Total transepithelial and transcellular Ca transport across fully differentiated Caco-2 cell monolayers was significantly increased by TNF- $\alpha$ treatment $(P<0 \cdot 001)$, but was unaffected by lipid treatment $(P>0 \cdot 1)$. There were trends for a significant $(P=0.062-0.064)$ interaction between the two factors (Table 2). One-way ANOVA showed that treatment of nonTNF- $\alpha$-treated Caco- 2 cell monolayers with $80 \mu \mathrm{M}-22: 6 n-3$, but not $80 \mu \mathrm{M}-20: 5 n-3$ or $40 \mu \mathrm{M}-20: 5 n-3+40 \mu \mathrm{M}-22: 6 n$ 3 , significantly $(P<0.005)$ increased total transepithelial and transcellular $\mathrm{Ca}$ transport compared with control (Table 2). Exposure of TNF- $\alpha$-treated Caco- 2 cell monolayers to $80 \mu \mathrm{M}-20: 5 n-3,80 \mu \mathrm{M}-22: 6 n-3$ or $40 \mu \mathrm{M}-20: 5 n-3+40 \mu \mathrm{M}-$ $22: 6 n-3$ had no significant effect on total transepithelial or transcellular $\mathrm{Ca}$ transport relative to the control (Table 2).

Paracellular Ca transport across fully differentiated Caco-2 cell monolayers was significantly influenced by lipid treatment $(P \leq 0.0001)$, but was unaffected by TNF- $\alpha$ treatment and there was no significant $(P>0 \cdot 1)$ interaction between the treatments (Table 2).

TEER across fully differentiated Caco- 2 cell monolayers was significantly $(P<0.0001)$ increased by lipid treatment and significantly $(P<0.0001)$ decreased by TNF- $\alpha$ treatment, and there was a significant $(P=0 \cdot 01)$ interaction between the two factors. Treatment of non-TNF- $\alpha$-treated Caco- 2 cell monolayers with $80 \mu \mathrm{M}-20: 5 n-3,80 \mu \mathrm{M}-22: 6 n-3$ and $40 \mu \mathrm{M}-$ $20: 5 n-3+40 \mu \mathrm{M}-22: 6 n-3$ significantly $(P<0 \cdot 001)$ increased TEER compared with control (Table 2). Treatment of TNF- $\alpha-$ treated Caco-2 cell monolayers with $80 \mu \mathrm{M}-20: 5 n-3$ and $80 \mu \mathrm{M}-22: 6 n-3$, but not $40 \mu \mathrm{M}-20: 5 n-3+40 \mu \mathrm{M}-22: 6 n-3$ significantly $(P<0 \cdot 001)$ increased TEER compared with control (Table 2$)$. TNF- $\alpha$-treated cells had significantly $(P \leq 0 \cdot 0001)$ 

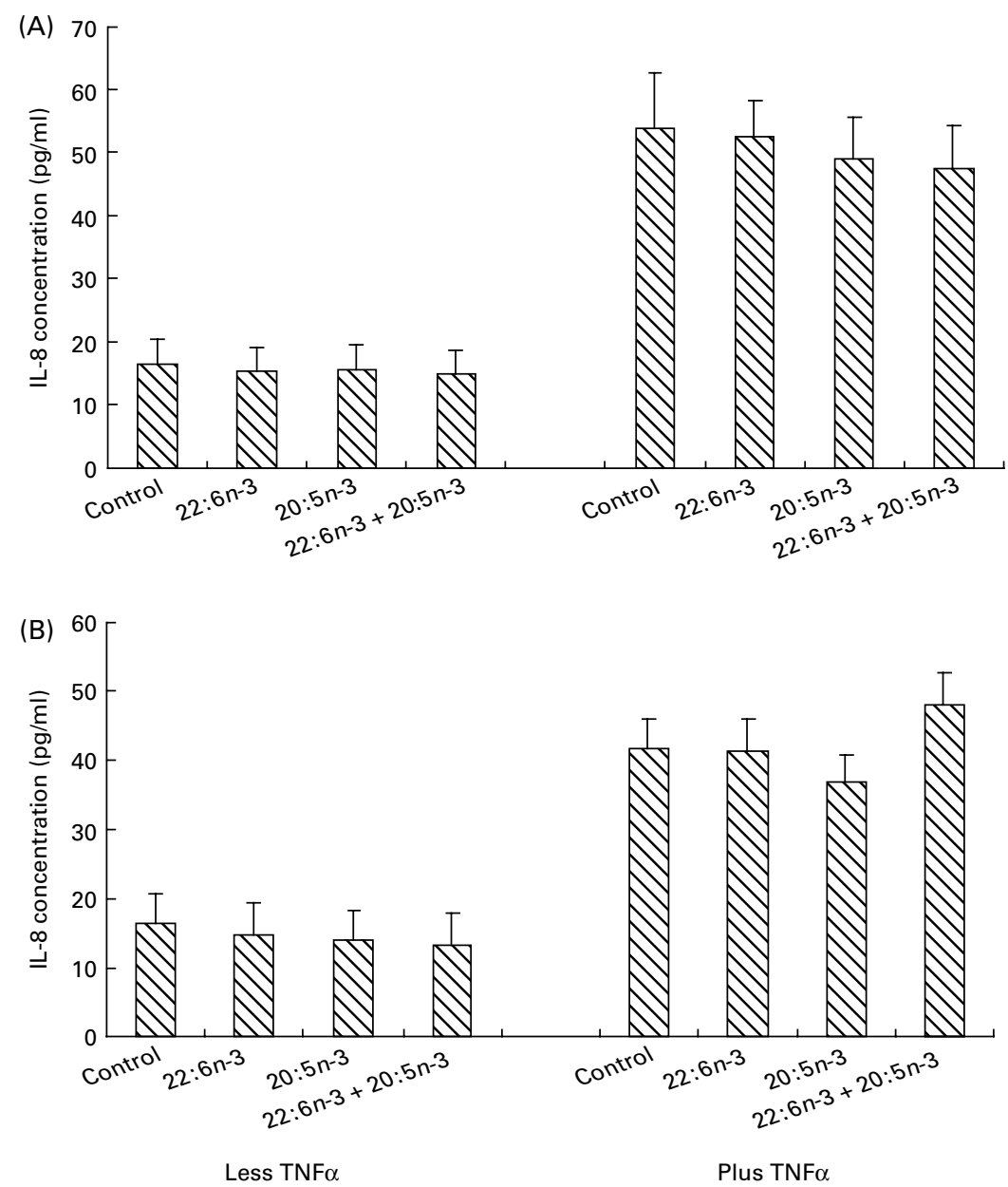

Fig. 1. The effect of $n-3$ fatty acid treatment on IL-8 secretion from fully differentiated Caco-2 cell monolayers in (A) preventative studies and (B) therapeutic studies (for details, see p. 283). Data are mean values $(n 11-13)$, with standard errors represented by vertical bars. Mean values for TNF- $\alpha$-treated $(10 \mathrm{ng} / \mathrm{ml}$ ) cells were significantly different from those of controls in both preventative and therapeutic studies $(P \leq 0.0001)$. There was no significant effect of $n-3$ fatty acid treatment and no significant interactions with TNF- $\alpha$ treatment in either preventative or therapeutic studies $(P>0 \cdot 1)$.

lower TEER compared with untreated cells, irrespective of the lipid treatment (Table 2).

IL-8 secretion from fully differentiated Caco- 2 cell monolayers was significantly increased by TNF- $\alpha$ treatment $(P \leq 0.0001)$, but was unaffected by lipid treatment $(P>0.05)$ and there was no significant $(P>0 \cdot 05)$ interaction between the treatments (Fig. 1(B)).

\section{Discussion}

Caco- 2 cells have been suggested to be a suitable model for predicting intestinal $\mathrm{Ca}$ absorption in man (Giuliano \& Wood, 1991; Fleet \& Wood, 1999). While Caco-2 cells are colonocytes in origin, in culture, they spontaneously differentiate and form a polarised epithelial monolayer with tight junctions and express a differentiated cell phenotype consistent with absorptive small intestine-like enterocytes (Pinto et al. 1983; Yee, 1997). In particular, these cells have a functional vitamin D receptor (Giuliano et al. 1991) and have Ca transport kinetics that suggest the presence of both a saturable and non-saturable $\mathrm{Ca}$ transport pathway, similar to what has been observed in human and animal intestine (Fleet
\& Wood, 1999). 1,25 Dihydroxyvitamin $\mathrm{D}_{3}$ treatment induces the saturable, but not diffusional, component of Ca transport (Giuliano \& Wood, 1991) and induces accumulation of calbindin $\mathrm{D}_{9 \mathrm{~K}}$ mRNA in these cells (Fleet \& Wood, 1994).

In the present study, treatment with $20: 5 n-3$ and $22: 6 n-3$, separately, and in combination, over $8 \mathrm{~d}$ (preventative studies) significantly enhanced total transepithelial $\mathrm{Ca}$ transport in non-inflamed Caco-2 cell monolayers. This enhancement was related to an increased rate of transcellular $\mathrm{Ca}$ transport. The stimulatory effect of the $20: 5 n-3$ and $20: 5 n$ $3+22: 6 n-3$ on total and transcellular $\mathrm{Ca}$ transport was less evident, just failing to reach statistical significance, in cells treated in the therapeutic studies, and even though the stimulatory effects of $22: 6 n-3$ on these parameters were statistically significant, they were of less magnitude than those seen in the preventative studies. However, the treatment with fatty acids in the therapeutic studies was for $6 \mathrm{~d}$ as opposed to the $8 \mathrm{~d}$ in the preventative studies, which may have lessened their effect on $\mathrm{Ca}$ transport. The duration of exposure was chosen because $6 \mathrm{~d}$ has been shown to be sufficient to allow fatty acid uptake into Caco- 2 cells. The present findings in human intestinal-like Caco- 2 cells, a good in vitro 
model for Ca absorption in man (Giuliano \& Wood, 1991; Fleet \& Wood, 1999), support the findings from animal studies. For example, Haag \& Kruger (2001) reported that $n-3$ fatty acids, $20: 5 n-3$ and $22: 6 n-3$, enhanced duodenal Ca uptake in rats. Coetzer et al. (1994) found that fish oil (rich in 20:5n-3 and 22:6n-3) significantly enhanced $\mathrm{Ca}$ transport across brush-border membranes of rat intestinal cells, while oils such as evening primrose and sunflowerseed (both particularly high in $18: 1 n-9$ and $18: 2 n-6$ ) or coconut oil (particularly rich in 12:0, 14:0 and 16:0) had no effects on $\mathrm{Ca}$ transport. While not investigated in the present study, the mechanism by which the $n-3$ fatty acids stimulated transcellular Ca transport may be related to effects at the basolateral membrane (i.e. $\mathrm{Ca}$ extrusion); their modulation of $\mathrm{Ca}^{2+}$-ATPase and $\mathrm{Na}^{+}, \mathrm{K}^{+}$-ATPase activity is either by a direct action on the enzyme or by phosphorylation processes via protein kinases A and C (Haag \& Kruger, 2001; Haag et al. 1999, 2003) and/or influencing Ca uptake at the brush border by changing the phospholipids composition and therefore, possibly permeability (Coetzer et al. 1994). In the present study, only a very low proportion of overall $\mathrm{Ca}$ transport in our Caco-2 cells occurred by the paracellular route (about 4-6\%). Furthermore, in general, treatment with $n-3$ fatty acids had little, if any, effects on this mode of Ca transport.

In the present study, a model of inflamed intestinal cells, typical of that in Crohn's disease patients, was achieved by treatment of Caco-2 cells with TNF- $\alpha$. TNF- $\alpha$ treatment of Caco-2 cells led to significantly higher levels of the chemokine, IL-8, which has a central role in attracting neutrophils to the inflamed mucosa. However, $n-3$ fatty acid treatment did not appear to prevent or lower the induction of this biomarker of inflammation upon treatment of Caco-2 cells with TNF- $\alpha$, or therapeutically lessen the production of IL- 8 in already induced cells. It must be emphasised, however, that effects on the inflammatory process per se were not included as a primary outcome measure in our studies, because we were cognisant of the fact that Caco-2 cells, as an in vitro monoculture model, lack the complex interactions and communications with immune cells that exist in vivo. The present study also investigated the effect of $n-3$ fatty acids on intestinal inflammation from a luminal perspective, as opposed to the more systemic effect. Interestingly, a recent study in Caco- 2 cells showed that allicin, a bioactive substance present in freshly crushed garlic, inhibited the TNF- $\alpha$-induced secretion of a number of cytokines, including IL-8, suggesting an attenuation of intestinal inflammation by a luminal food bioactive compound (Lang et al. 2004). Notwithstanding this lack of effect on the biomarker of inflammation in the present study, treatment with $n-3$ fatty acids for $8 \mathrm{~d}$ (preventative studies) appeared to promote total transepithelial and transcellular $\mathrm{Ca}$ transport in TNF- $\alpha$-treated Caco- 2 cell monolayers. On the other hand, treatment of Caco-2 cells with $22: 6 n-3$ for $6 \mathrm{~d}$ following TNF- $\alpha$ treatment for $48 \mathrm{~h}$ (therapeutic studies) failed to stimulate total and transcellular $\mathrm{Ca}$ transport, while $20: 5 n-3$ and $20: 5 n-3+22: 6 n-3$ did promote these modes of $\mathrm{Ca}$ transport. As with case of non-TNF- $\alpha$-treated Caco-2 cells, the slightly shorter duration of treatment in the therapeutic studies may have lessened their effect on Ca transport, with the magnitude of stimulation less than that seen in the preventative studies. The reason for the differential effects 
of 22:6n-3 on total and transcellular $\mathrm{Ca}$ transport between preventative and therapeutic studies is unclear, but, while not assessed in the present study, it may be related to possible different uptake efficiencies of the fatty acid or effects on gene transcription between cells in which inflammation was acute (over $48 \mathrm{~h}$; preventative studies) compared with longer-term (over $8 \mathrm{~d}$; therapeutic studies).

The findings of the present study also showed that treatment of Caco- 2 cells with acute $(48 \mathrm{~h})$ and longer-term $(8 \mathrm{~d})$ treatment with $\mathrm{TNF}-\alpha$, independent of lipid treatment, increased total transepithelial and transcellular $\mathrm{Ca}$ transport, lowered TEER but had no effect on paracellular $\mathrm{Ca}$ transport. While there are no reports in the literature of the effect of TNF- $\alpha$ on $\mathrm{Ca}$ transport, these effects on both transcellular and paracellular transport were somewhat unexpected. In relation to paracellular transport, there are several reports of an enhanced paracellular permeability (and reduced TEER) across Caco-2 cell monolayers treated with TNF- $\alpha$ (Marano et al. 1998; Ma et al. 2004, 2005; Lang et al. 2004). However, as mentioned already, only a very low proportion of overall Ca transport in our Caco- 2 cells occurred by the paracellular route, possibly making it difficult to detect effects of TNF- $\alpha$ (or lipid) treatments. In fact, TEER across Caco- 2 cell monolayers was significantly reduced by treatment with $\mathrm{TNF}-\alpha$, possibly suggesting a loosening of tight junctions. While not providing evidence of enhanced Ca uptake, Schmidt et al. (1995) showed that patients with active Crohn's disease (or ulcerative colitis) (and in whom TNF- $\alpha$ would be expected to be elevated) had moderately higher $\mathrm{Ca}^{2+}$ levels in colon biopsies samples compared with that in healthy controls. Furthermore, there was a significant decrease in intracellular $\mathrm{Ca}^{2+}$ concentration in patients with quiescent disease who were receiving maintenance therapy (and in whom TNF- $\alpha$ would be expected to be largely normalised). The effect of TNF- $\alpha$ on intestinal $\mathrm{Ca}$ handling requires further investigation to understand its physiological and pathophysiological relevance.

Further research in intestinal cells in culture may help improve our understanding of the mechanistic aspects of the effects of marine oil-derived fatty acids on Ca absorption. However, as a better understanding of the effect of these fatty acids on $\mathrm{Ca}$ absorption in human subjects is the ultimate goal, research is urgently required on the influence of marine oil-based $n-3$ fatty acids on $\mathrm{Ca}$ absorption in vivo in studies of healthy human subjects as well as of Crohn's disease patients, an area which to date has not received much research emphasis.

\section{References}

Arnaud SB, Goldsmith RS, Lambert PW \& Go VL (1975) 25-Hydroxyvitamin D3: evidence of an enterohepatic circulation in man. Proc Soc Exp Biol Med 149, 570-572.

Belluzzi A (2002) $n-3$ Fatty acids for the treatment of inflammatory bowel diseases. Proc Nutr Soc 61, 391-395.

Bernstein CN, Seeger LL, Anton PA, Artinian L, Geffrey S, Goodman W, Belin TR \& Shanahan F (1996) A randomized, placebo-controlled trial of calcium supplementation for decreased bone density in corticosteroid-using patients with inflammatory bowel disease: a pilot study. Aliment Pharmacol Ther 10, 777-786.

Bjarnason I, Macpherson A, Mackintosh C, Buxton-Thomas M, Forgacs I \& Moniz C (1997) Reduced bone density in patients with inflammatory bowel disease. Gut 40, 228-233.
Cashman KD \& Shanahan F (2003) Is nutrition an aetiological factor for inflammatory bowel disease? Eur J Gastroenterol Hepatol 15, $607-613$.

Coetzer H, Claassen N, van Papendorp DH \& Kruger MC (1994) Calcium transport by isolated brush border and basolateral membrane vesicles: role of essential fatty acid supplementation. Prostaglandins Leukot Essent Fatty Acids 50, 257-266.

Compston JE \& Creamer B (1977) Plasma levels and intestinal absorption of 25-hydroxyvitamin D in patients with small bowel resection. Gut 18, 171-175.

Duggan P, O’Brien M, Kiely M, McCarthy J, Shanahan F \& Cashman KD (2004) Vitamin K status in patients with Crohn's disease and relationship to bone turnover. Am J Gastroenterol 99, 2178-2185.

Edmonson JM, Armstrong LS \& Martinez AO (1988) A rapid and simple MTT-based assay for determining drug sensitivity in monolayer cultures. J Tissue Cult Methods 11, 15-17.

Endres S, Lorenz R \& Loeschke K (1999) Lipid treatment of inflammatory bowel disease. Curr Opin Clin Nutr Metab Care 2, 117-120.

Fleet JC \& Wood RJ (1994) Identification of calbindin D-9k mRNA and its regulation by 1,25-dihydroxyvitamin $\mathrm{D}_{3}$ in Caco-2 cells. Arch Biochem Biophys 308, 171-174.

Fleet JC \& Wood RJ (1999) Specific 1,25(OH $)_{2} \mathrm{D}_{3}$-mediated regulation of transcellular calcium transport in Caco-2 cells. Am J Physiol 276, G958-G964.

Giuliano AR, Franceschi RT \& Wood RJ (1991) Characterization of the vitamin D receptor from the Caco-2 human colon carcinoma cell line: effect of cellular differentiation. Arch Biochem Biophys 285, 261-269.

Giuliano AR \& Wood RJ (1991) Vitamin D-regulated calcium transport in Caco-2 cells: unique in vitro model. Am J Physiol 260, G207-G212.

Haag M \& Kruger MC (2001) Upregulation of duodenal calcium absorption by poly-unsaturated fatty acids: events at the basolateral membrane. Med Hypotheses 56, 637-640.

Haag M, Magada ON, Claassen N, Bohmer LH \& Kruger MC (2003) Omega-3 fatty acids modulate ATPases involved in duodenal $\mathrm{Ca}$ absorption. Prostaglandins Leukot Essent Fatty Acids $\mathbf{6 8}$, 423-429.

Haag M, Vermeulen F, Magada O \& Kruger MC (1999) Polyunsaturated fatty acids inhibit $\mathrm{Mg}^{2+}$-ATPase in basolateral membranes from rat enterocytes. Prostaglandins Leukot Essent Fatty Acids 61, 25-27.

Haderslev KV, Jeppesen PB, Sorensen HA, Mortensen PB \& Staun M (2003) Vitamin D status and measurements of markers of bone metabolism in patients with small intestinal resection. Gut 52, $653-658$.

Jewell C \& Cashman KD (2003) The effect of conjugated linoleic acid and medium-chain fatty acids on transepithelial calcium transport in human intestinal-like Caco-2 cells. Br J Nutr 89, 639-647.

Jewell C, Cusack S \& Cashman KD (2005) The effect of conjugated linoleic acid on transepithelial calcium transport and mediators of paracellular permeability in human intestinal-like Caco-2 cells. Prostaglandins Leukot Essent Fatty Acids 72, 163-171.

Kennefick S \& Cashman KD (2000) Investigation of an in vitro model for predicting the effect of food components on calcium availability from meals. Int J Food Sci Nutr 51, 45-54.

Kruger MC \& Horrobin DF (1997) Calcium metabolism, osteoporosis and essential fatty acids: a review. Prog Lipid Res 36, 131-151.

Lang A, Lahav M, Sakhnini E, Barshack I, Fidder HH, Avidan B, Bardan E, Hershkoviz R, Bar-Meir S \& Chowers Y (2004) Allicin inhibits spontaneous and TNF-alpha induced secretion of proinflammatory cytokines and chemokines from intestinal epithelial cells. Clin Nutr 23, 1199-1208.

Lindmark T, Kimura Y \& Artursson P (1998) Absorption enhancement through intracellular regulation of tight junction permeability by medium chain fatty acids in Caco-2 cells. J Pharmacol Exp Ther 284, 362-369. 
Ma TY, Boivin MA, Ye D, Pedram A \& Said HM (2005) Mechanism of TNF- $\alpha$ modulation of Caco-2 intestinal epithelial tight junction barrier: role of myosin light-chain kinase protein expression. Am J Physiol 288, G422-G430.

Ma TY, Iwamoto GK, Hoa NT, Akotia V, Pedram A, Boivin MA \& Said HM (2004) TNF-alpha-induced increase in intestinal epithelial tight junction permeability requires NF-kappa B activation. Am J Physiol 286, G367-G376.

Marano CW, Lewis SA, Garulacan LA, Soler AP \& Mullin JM (1988) Tumor necrosis factor-alpha increases sodium and chloride conductance across the tight junction of CACO-2 BEE, a human intestinal epithelial cell line. J Membr Biol 161, 263-274.

Mossman T (1983) Rapid colorimetric assay for cellular growth and survival: application to proliferation and cytotoxicity assays. J Immunol Methods 65, 55-63.

O'Hara AM, O'Regan P, Fanning A, O'Mahony C, Macsharry J, Lyons A, Bienenstock J, O'Mahony L \& Shanahan F (2006) Functional modulation of human intestinal epithelial cell responses by Bifidobacterium infantis and Lactobacillus salivarius. Immunology 118, 202-215.

Pinto M, Robine-Leon S, Appay MD, et al. (1983) Enterocyte-like differentiation and polarization of the human colon carcinoma cell line Caco-2 in culture. Biol Cell 47, 323-330.

Pollak RD, Karmeli F, Eliakim R, Ackerman Z, Tabb K \& Rachmilewitz D (1998) Femoral neck osteopenia in patients with inflammatory bowel disease. Am J Gastroenterol 93, 1483-1490.

Ryan BM (2004) Effects of fatty acids on calcium uptake in an in vitro cell culture model. MSc Thesis, National University of Ireland, Cork.
Schmidt C, Kosche E, Baumeister B \& Vetter H (1995) Arachidonic acid metabolism and intracellular calcium concentration in inflammatory bowel disease. Eur J Gastroenterol Hepatol 7, $865-869$.

Schoon EJ, Muller MC, Vermeer C, Schurgers LJ, Brummer RJ \& Stockbrugger RW (2001) Low serum and bone vitamin K status in patients with longstanding Crohn's disease: another pathogenetic factor of osteoporosis in Crohn's disease? Gut 48, 473-477.

Scott EM, Gaywood I \& Scott BB (2000) Guidelines for osteoporosis in coeliac disease and inflammatory bowel disease. British Society of Gastroenterology. Gut 46, S1-S8.

Silvennoinen J, Lamberg-Allardt C, Karkkainen M, Niemela S \& Lehtola J (1996) Dietary calcium intake and its relation to bone mineral density in patients with inflammatory bowel disease. J Intern Med 240, 285-292.

Snedecor GW \& Cochran WG (1967) Statistical Methods. Ames, IA: Iowa State University Press.

Szulc P \& Meunier PJ (2001) Is vitamin K defiency a risk factor for osteoporosis in Crohn's disease? Lancet 357, 1995-1996.

Tanaka Y, Taki Y, Sakane T, Nadai T, Sezaki H \& Yamashita S (1995) Characterization of drug transport through tight-junctional pathway in Caco-2 monolayer: comparison with isolated rat jejunum and colon. Pharm Res 12, 523-528.

Watkins BA, Lippman HE, Le Bouteiller L, Li Y \& Seifert MF (2001) Bioactive fatty acids: role in bone biology and bone cell function. Prog Lipid Res 40, 125-148.

Yee S (1997) In vitro permeability across Caco-2 cells (colonic) can predict in vivo (small intestinal) absorption in man - fact or myth. Pharmacol Res 14, 763-766. 